\title{
An N-Heterocyclic Carbene with a Saturated Backbone and Spatially-Defined Steric Impact
}

\author{
Gillian Laidlaw, Susanna H. Wood, Alan R. Kennedy, and David J. Nelson* \\ Dedicated to Dr Mark Spicer in recognition of his 27 years of service to the Department of Pure and Applied Chemistry
}

\begin{abstract}
The synthesis and coordination chemistry of a saturated analogue of a 'bulky-yet-flexible' N-heterocyclic carbene (NHC) ligand are described. "SIPaul" is a 4,5-dihydroimidazol-2-ylidene ligand with unsymmetrical aryl $\mathrm{N}$-substituents, and is one of the growing class of 'bulky-yet-flexible' NHCs that are sufficiently bulky to stabilise catalytic intermediates, but sufficiently flexible that they do not inhibit productive chemistry at the metal centre. Here, the synthesis of SIPaul. $\mathrm{HCl}$ and its complexes with copper, silver, iridium, palladium, and nickel, and its selenourea, are reported. The steric impact of the ligand is quantified using percent buried volume $\left(\% V_{\text {bur }}\right)$, while the electronic properties are probed and quantified using the Tolman Electronic Parameter (TEP) and $\delta_{\text {se }}$ of the corresponding selenourea. This work shows that despite the often very different performance of saturated versus unsaturated carbenes in catalysis, the effect of backbone saturation on measurable properties is very small.
\end{abstract}

\section{Introduction}

The synthesis, characterisation, and application of new ligands is a crucial area of research that drives progress in applications that rely upon transition metal complexes. $\mathrm{NHCs}^{[1-3]}$ have a number of often very favourable electronic ${ }^{[4-5]}$ and steric properties; ${ }^{[6-7]}$ they tend to be very electron-donating, and present their steric bulk in an 'umbrella' arrangement rather than, for example, in the form of a cone with a vertex at the metal. ${ }^{[8]}$ Importantly, most common imidazol-2-ylidenes and 4,5dihydroimidazol-2-ylidenes are readily-prepared from the corresponding amine in a short series of high-yielding and scalable synthetic steps. ${ }^{[9]}$ This typically convenient and modular approach to NHC synthesis provides the opportunity to finely tune ligand structure, and therefore ligand properties, by designing and preparing the appropriate amine (Scheme 1 (a) shows a general route).

We recently disclosed the synthesis of the ligand precursor IPaul. $\mathrm{HCl}$ (1) and the coordination chemistry of the corresponding $\mathrm{NHC}$ ligand IPaul (2), which bears 2(diphenylmethyl)-4,6-dimethylphenyl $\mathrm{N}$-substituents (Scheme 1 (b)). ${ }^{[10]}$ This ligand was coordinated to copper, silver, nickel, and

[a] G. Laidlaw, S. H. Wood, A. R. Kennedy, D. J. Nelson* WestCHEM Department of Pure and Applied Chemistry University of Strathclyde

295 Cathedral Street, Glasgow, G1 1XL, UK

E-mail: david.nelson@strath.ac.uk

Supporting information for this article is given via a link at the end of the document. The raw data underpinning this work can be downloaded from the Strathclyde PURE data repository at the following URL: http://dx.doi.org/[to be added if/when accepted]

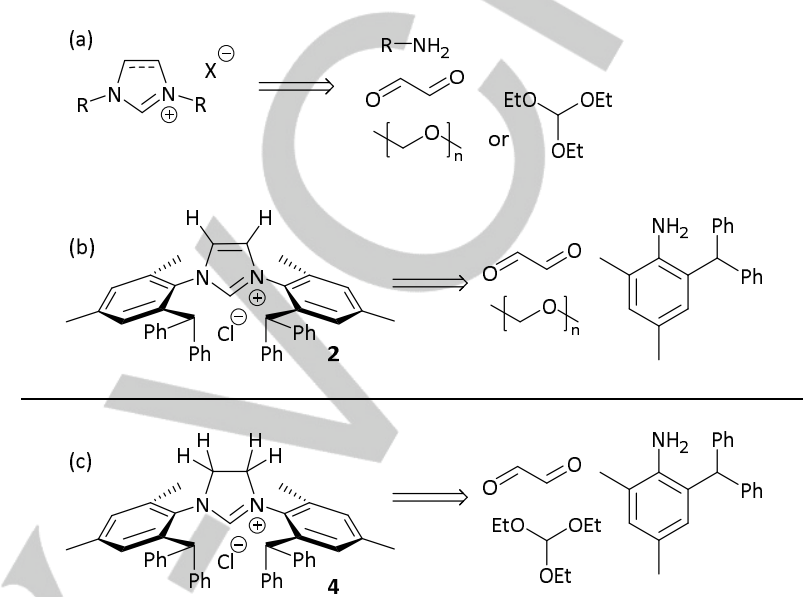

Scheme 1. (a) Modular synthesis of imidazolium and 4,5-hydroimidazolium precursors to NHC ligands. (b) Synthesis of IPaul. $\mathrm{HCl}$ (2). (c) Synthesis of $\mathrm{SIPaul} . \mathrm{HCl}$ (4; this work).

iridium. Two different rotamers of the ligand were obtained: one in which the diphenylmethyl groups were on the same side of the imidazol-2-ylidene core (syn), and one in which they were on opposite sides (anti). Unsurprisingly, the Tolman Electronic Parameter $(T E P)^{[8]}$ - a measure of the net electron-donating effect of a ligand - was very similar for IPaul and analogous carbenes such as IPr*. Steric maps and buried volume $\left(\% V_{b u r}\right)$ calculations showed that while the overall steric impact of $\mathbf{2}$ was similar to IPr in most coordination environments, the distribution of this steric bulk was focused on one side of the carbene (IPr = 1,3-bis(2,6-diisopropylphenyl)imidazol-2-ylidene). The copper complex $[\mathrm{CuCl}(2)]$ was shown to be more active than analogous complexes with smaller (e.g. IMes) or larger (e.g. IPr*) NHCs for the hydrosilylation of a prototypical substrate.

Despite their structural similarity, 4,5-dihydroimidazol-2ylidenes can have quite different properties to the corresponding imidazol-2-ylidenes. The TEPs for the latter tend to be higher, which is suggestive of lower net electron density at the metal centre $;{ }^{[11]}$ however, this effect is most likely due to the increased back bonding from the electron-rich nickel( 0$)$ or iridium $(\mathrm{I})$ centre to the non-aromatic dihydroimidazol-2-ylidene core, compared to the imidazol-2-ylidene core. ${ }^{[12-16]}$ As well as changes in the electronic properties of the ligand, the saturated and flexible nature of the backbone can allow different conformational and steric properties. These can be difficult to gauge using static measures such as $\% V_{\text {bur }}$ but might have considerable effects in catalysis.

Here, we report complexes of the saturated analogue of IPaul (referred to here as SIPaul (3)), and studies to probe its electronic and steric properties; Scheme 1 (c) outlines our overall approach to SIPaul. $\mathrm{HCl}(4)$ which serves as the ligand 
precursor for this work, and was coordinated to a range of metals without the need to liberate and isolate the free carbene. ${ }^{[17]}$

\section{Results and Discussion}

The synthesis of the target ligand was achieved straightforwardly from diimine 5 (Scheme 2). ${ }^{[10]}$ The reduction of 5 with aluminium hydride reagent 6 led to the diamine $\mathbf{7}$ in good yield. Cyclisation of this diamine was initially somewhat problematic, and initial attempts to achieve this thermally using methods that are used to prepare SIPr were not successful, or provided very low yields. ${ }^{[18]}$ However, a microwave-mediated reaction provided the target compound SIPaul. $\mathrm{HCl}(4)$ in $86 \%$ yield. Notably, the synthesis of such bulky 4,5dihydroimidazolium salts is often very challenging, and alternative multi-step routes can be required. ${ }^{[19]} 3$ is one of the bulkier 4,5-dihydroimidazol-2-ylidenes that has been prepared.
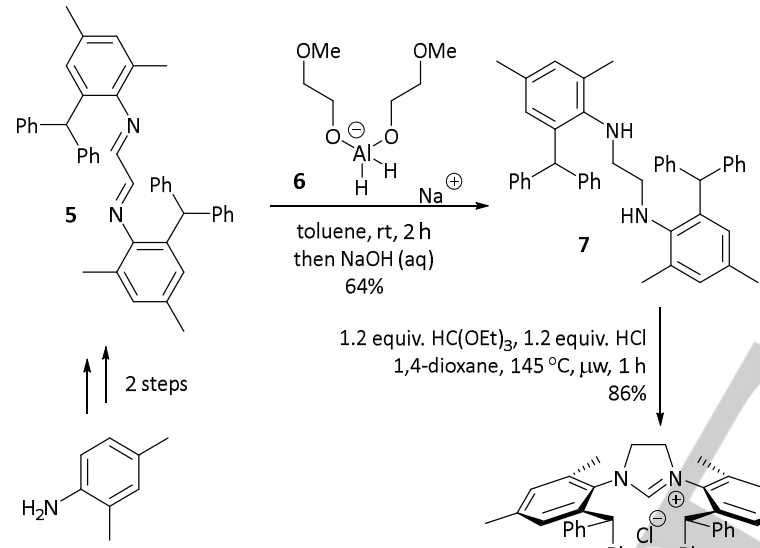

1.2 equiv. $\mathrm{HC}(\mathrm{OEt})_{3}, 1.2$ equiv. $\mathrm{HCl}$
1,4 -dioxane, $145^{\circ} \mathrm{C}, \mu \mathrm{w}, 1 \mathrm{~h}$

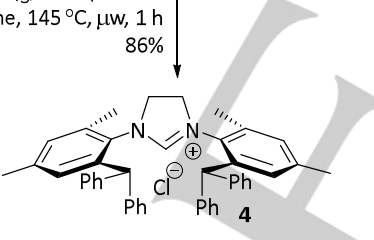

Scheme 2. Synthesis of SIPaul. $\mathrm{HCl}$ (4). The compound is obtained as a 2:1 mixture of rotamers.

The resulting imidazolium salt (4) was fully characterised using ${ }^{1} \mathrm{H}$ and ${ }^{13} \mathrm{C}\left\{{ }^{1} \mathrm{H}\right\}$ NMR spectroscopy, elemental analysis, and high-resolution mass spectrometry. Analogously to IPaul. $\mathrm{HCl}$ (1), 4 exists as a mixture of two rotamers: a synrotamer where the two diphenylmethyl groups are on the same side of the NHC core, and an anti-isomer where the two diphenylmethyl groups are on opposite sides (Figure 1). DFT calculations of the structure and behaviour of IPaul (2) and SIPaul (3) were carried out (B3LYP/6-31G(d) in the gas phase). These indicated that the anti-conformer of $\mathbf{3}$ is favoured by 2.6 $\mathrm{kcal} \mathrm{mol}^{-1}$, and that the barrier for conversion between the two isomers is $15.7 \mathrm{kcal} \mathrm{mol}^{-1}$ (Figure 1 (a)). These data can be compared to the analogous calculations for 2 , which show that the anti-conformer is preferred by $2.8 \mathrm{kcal} \mathrm{mol}^{-1}$, and that there is a $16.8 \mathrm{kcal} \mathrm{mol}^{-1}$ barrier to rotation (Figure 1 (b)). These data are consistent with the observation of two distinct isomers of 1 and $\mathbf{4}$ in solution by NMR spectroscopy.
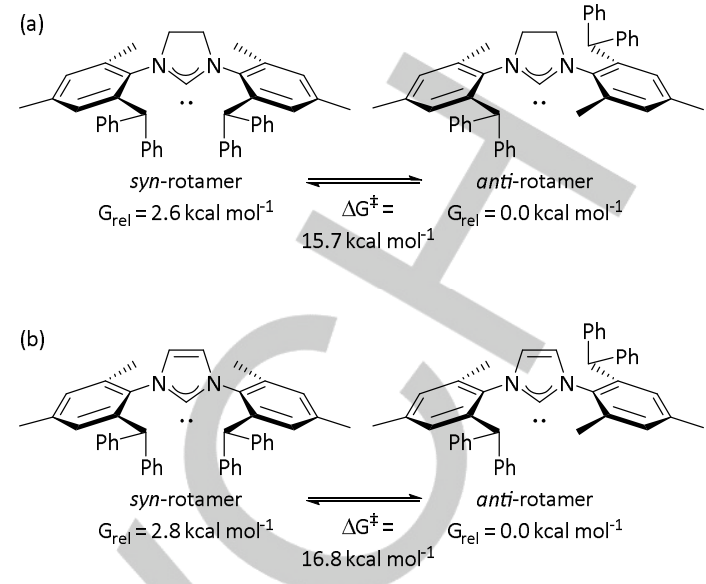

Figure 1. Computational study of rotamers of (a) SIPaul (3) and (b) IPaul (2).

A series of organometallic complexes were prepared using established methodologies that preclude the need to first prepare, isolate, and purify the corresponding free carbene. In each case, 4 was exposed to a weak base in the presence of an appropriate metal precursor (Scheme 3). ${ }^{[17]}[\mathrm{AgCl}(\mathrm{SIPaul})](8)$ was prepared using $\mathrm{AgNO}_{3},{ }^{[20]}[\mathrm{CuCl}(\mathrm{SIPaul})](9)$ using $\mathrm{CuCl},{ }^{[21]}$ and $[\operatorname{IrCl}(\mathrm{COD})(\mathrm{SIPaul})] \quad(10)$ using $[\operatorname{Ir}(\mu-\mathrm{Cl})(\mathrm{COD})]_{2}{ }^{[22]}$ $[\mathrm{NiCl}(\mathrm{Cp})(\mathrm{SIPaul})]$ (11) was prepared by heating 4 in THF solution in the presence of $\mathrm{NiCp}_{2} .^{[23]}$ All new complexes were characterised by methods including ${ }^{1} \mathrm{H}$ and ${ }^{13} \mathrm{C}\left\{{ }^{1} \mathrm{H}\right\}$ NMR spectroscopy and X-ray crystallography. ${ }^{[24]}$ Most complexes were obtained as a mixture of rotamers in solution, as judged by NMR analysis, with a syn- or anti-arrangement of the diphenylmethyl groups, in varying ratios depending on the ligand sphere of the complex.

(a)

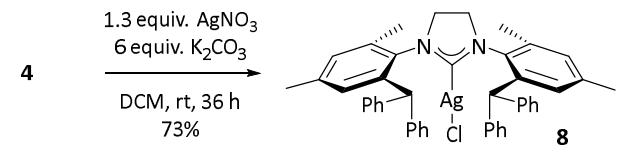

(b)

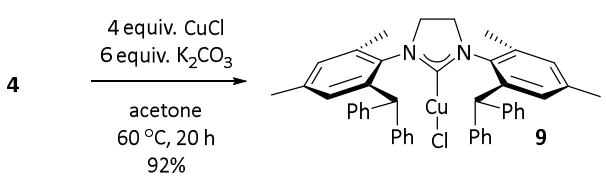

(c)

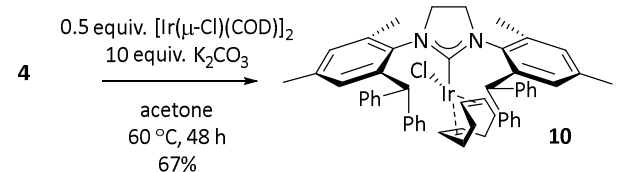

(d)

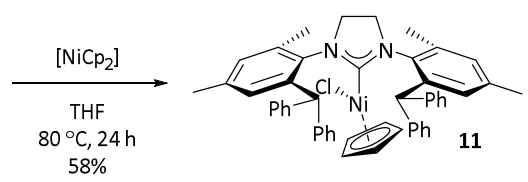

Scheme 3. Synthesis of metal complexes of SIPaul (3). All complexes are obtained as a mixture of rotamers (see text). 
The solid state molecular structures for these species are presented in Figure 2. The syn-arrangement was found to predominate in the solid state, as determined by X-ray diffraction analyses of single crystals, despite this being the higher energy of the two conformations. Notably, similar trends were observed for IPaul complexes. ${ }^{[10]}$ This is likely to be as a result of favourable packing arrangements in the solid state. The crystal structures of $\mathbf{8}$ and $\mathbf{9}$ were found to be mutually isomorphous and isostructural. The structure of $\mathbf{1 1}$ contains a large amount of disordered $\mathrm{CHCl}_{3}$ solvent; this could not be modelled in a satisfactory manner and so its contribution to the structure was removed using the SQUEEZE routine within PLATON. ${ }^{[25][26]}$

The molecular structures were used to calculate the percent buried volume $\left(\% V_{\text {bur }}\right)^{[6-7]}$ This metric quantifies the percentage of a sphere of $3.5 \AA$ around the metal centre that is occupied by the ligand. Complexes $8-11$ feature different coordination numbers and geometries (linear two-coordinate; square planar four-coordinate; piano-stool) and so provide a means to assess the behaviour of $\mathbf{3}$ in different environments. The free web-based SambVca software was used to calculate $\% V_{\text {bur. }}{ }^{[27-28]}$ This prepares 'steric maps' which allow the steric impact of the ligand around the metal centre to be visualised using a contour map. ${ }^{[7,27]}$ Figure 3 displays the steric maps for complexes 8-11 and notes their $\% V_{\text {bur }}$ (per-quadrant and overall). The buried volumes of these complexes are relatively similar to those for IPaul, especially given the limits of accuracy in comparing $\% \mathrm{~V}_{\text {bur }}$ values $^{[7]}$ (Ag: 44.1 vs $43.3 \%$; $\mathrm{Cu}$ : $46.9 \%$ vs $45.7 \%$; Ir: $36.1 \%$ vs $36.5 \%$; Ni: 38.4 vs $40.0 \%$ ). The increased flexibility of the backbone does not lead to a significant change in the steric profile of the ligand, as far as can be determined by X-ray crystallographic measurements in the solid state.

Further compounds were made in order to evaluate the steric and electronic properties of SIPaul. Iridium complex 10 was exposed to carbon monoxide in chloroform solution, forming $\left[\mathrm{IrCl}(\mathrm{CO})_{2}(\mathrm{SIPaul})\right]$ (12) (Scheme 5). IR analysis of a DCM solution of 12 , as a thin film on sodium chloride plates, gave two signals for the carbonyl stretching vibrations (at 2065 and 1981 $\mathrm{cm}^{-1}$ ). Like the corresponding IPaul complex, only two signals were observed; the signals for each rotomeric form are therefore very close, and the limited resolution of IR spectrometers (typically $1-2 \mathrm{~cm}^{-1}$ ) precludes resolution of two signals for each rotamer. The average signal for 12 is $2023 \mathrm{~cm}^{-1}$, which compares to $2026 \mathrm{~cm}^{-1}$ for the IPaul congener. This suggests that SIPaul is slightly more electron donating than IPaul, but the difference is relatively small.

The selenourea derivative of 3 (compound 13) was prepared using previously published methodology, by stirring 4 , excess selenium powder, and potassium tert-butoxide in anhydrous THF overnight (Scheme 5). ${ }^{[15,}$ 29-30] We recently reported the corresponding derivative of IPaul (14). ${ }^{[30]}$ As first reported by Ganter, ${ }^{[14]} \delta_{\text {se }}$ for the selenourea provides a measurement of the degree of back-bonding into the NHC. ${ }^{[15-16]}$ For more electron-rich NHC scaffolds, a zwitterionic resonance form can be envisaged. ${ }^{[31]}$ This therefore gives valuable extra information about the electronic properties of NHCs. ${ }^{77}$ Se NMR analysis of 15 reveals two values for $\delta_{\mathrm{se}}$ of 151 and $140 \mathrm{ppm}$

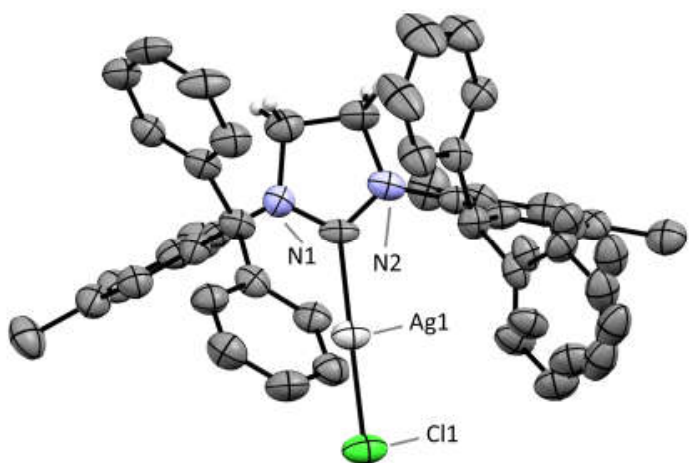

8
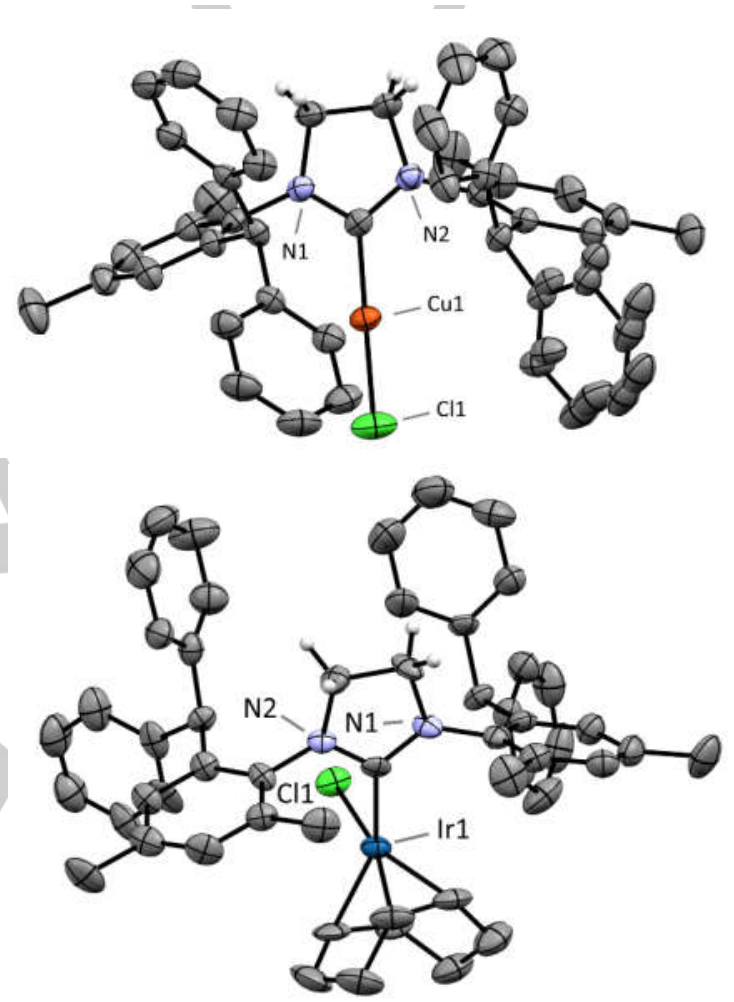

10

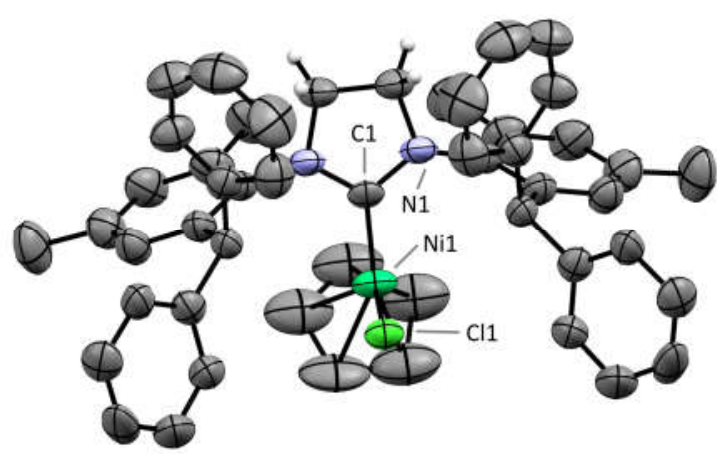

11

Figure 2. Molecular structures for $\mathbf{8}, \mathbf{9}, \mathbf{1 0}$, and $\mathbf{1 1}$, as determined by X-ray crystallographic analysis. Most hydrogen atoms are omitted for clarity. Thermal ellipsoids are drawn at 50\% probability. 

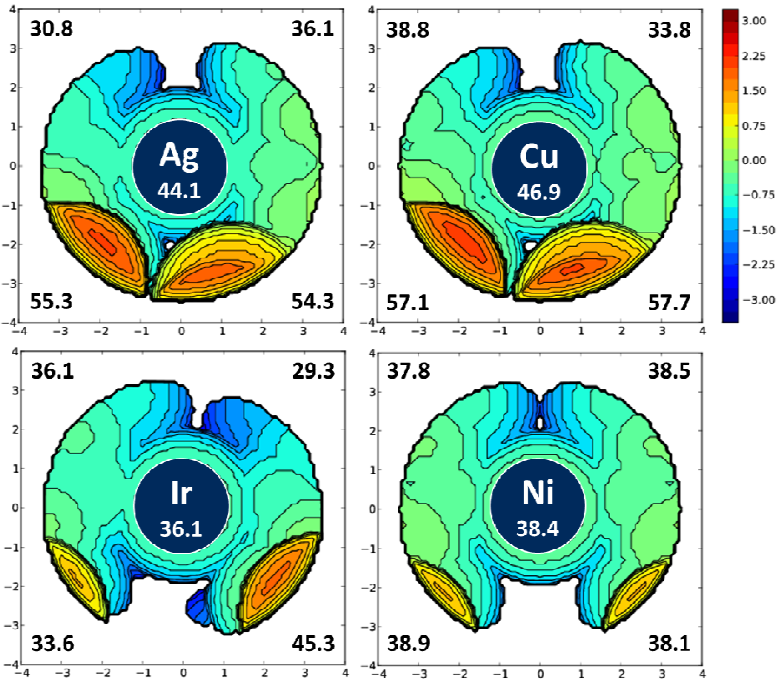

Figure 3. Steric maps and $\% V_{\text {bur }}$ for complexes $\mathbf{8}, \mathbf{9}, \mathbf{1 0}$, and 12 . The crystal structure of 10 contains two independent molecules, of which only one is presented here; the other has $\% V_{\text {bur }}=36.2$ and a very similar steric map.

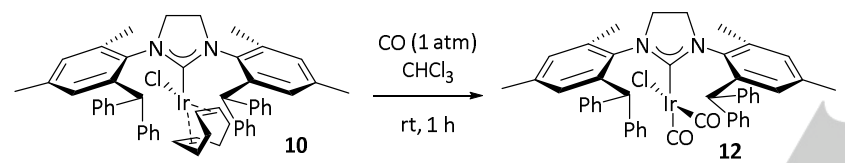

Scheme 4. Synthesis of $\left[\mathrm{IrCl}(\mathrm{CO})_{2}(\mathrm{IPaul})\right](12)$. The complex is obtained as a mixture of two rotamers.

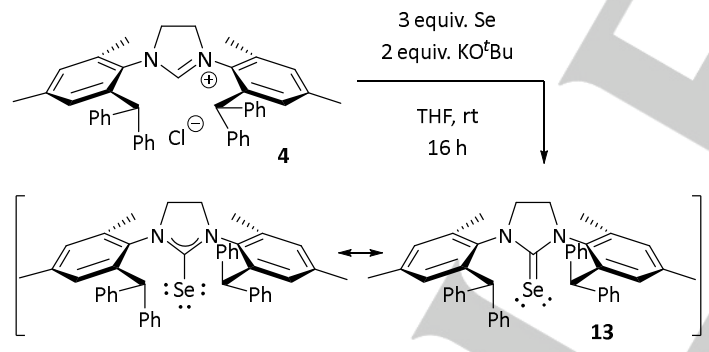

Scheme 5. Synthesis of 13 , which is obtained as a mixture of two rotamers.

(versus 64 and $51 \mathrm{ppm}$ for the IPaul derivative). This fits with other trends observed in this chemical shift value; $\delta_{\text {se }}$ for SIPaulSe lies between the values for SIPr-Se (190 ppm) and SIMes-Se $(110 \mathrm{ppm})$, in the same way that the values for IPaul-Se lie between those for IPr-Se (90 ppm) and IMes-Se (27 ppm).

Changes to the $\mathrm{N}$-aryl substituent clearly influence the $\pi$ accepting properties of the resulting $\mathrm{NHC}$, and so differences in reactivity between the corresponding $\mathrm{NHC}$ complexes may not be purely steric in nature.

Finally, initial catalytic tests were undertaken by applying 9 in the hydrosilylation of benzophenone (Scheme 6, Figure 4).
Our previous work showed that the corresponding IPau derivative was highly effective, ${ }^{[10]}$ outperforming complexes that

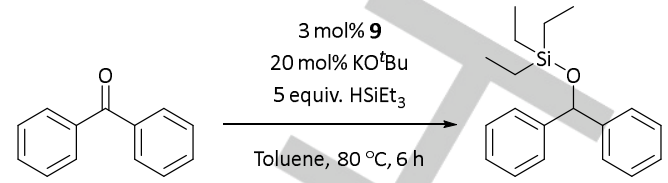

Scheme 6. Hydrosilylation of benzophenone catalysed by complex 9 .

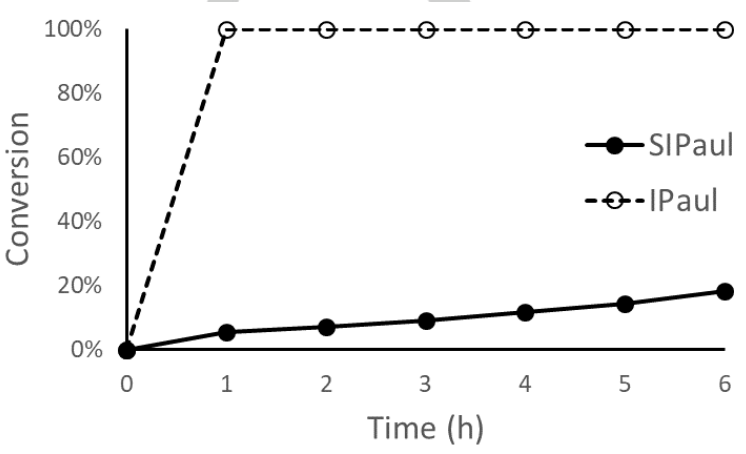

Figure 4. Kinetic study of the hydrosilylation of benzophenone catalysed by complex 9; data for the reaction catalysed by the analogous IPaul complex are taken from our previous study. ${ }^{[10]}$

bear smaller NHCs (such as IPr and IMes), while complexes of bulkier NHCs (such as $\mathrm{IPr}^{*}$ ) were very poor for this reaction. A kinetic study of this reaction, using $\mathbf{9}$ as a catalyst, showed that SIPaul is a substantially poorer catalyst for this reaction. The link between hydrosilylation performance and backbone saturation remains poorly understood; [CuX(SIMes)] complexes outperform the [CuX(IMes)] analogues, yet [CuX(SIPr)] complexes are far less effective catalysts for hydrosilylation than [CuX(IPr)] species. ${ }^{[32]}$ While this preliminary assessment of the potential for SIPaul as a ligand for homogenous catalysts is not particularly positive, the interplay of ligand structure and catalytic reactivity is complex and not well understood, and so we hope that it might find applications in alternative reactions.

\section{Conclusions}

This manuscript presents the synthesis of an NHC ligand ("SIPaul") in which a saturated backbone is combined with unsymmetrical $\mathrm{N}$-aryl substituents. Silver, copper, iridium, nickel, and selenourea compounds of this ligand are prepared and characterised, and used as models to examine the steric and electronic properties of the new carbene. SIPaul is one of the bulkier

SIPaul presents a broadly similar steric profile to IPaul, as judged from buried volume calculations. While a saturated backbone might be expected to impart additional flexibility to the ligand, the static picture from X-ray crystallography is very similar to that of the more constrained IPaul ligand. However, it 
must be noted that the situation for coordinatively-unsaturated intermediates in catalysis, in solution, might be rather different. There is still not a practical and informative way to reliably assess the dynamic steric influence of ligands and thus understand the degree and role of flexibility. SIPaul appears to be slightly more electron-donating, according to TEP measurements; $\delta_{S e}$ indicates that SIPaul is a better m-acceptor than IPaul, consistent with trends observed previously for carbene ligands with saturated versus unsaturated backbones.

Current research in our lab. is focussed on deploying IPaul and SIPaul complexes in catalysis, and more fully understanding the effect of structural features on catalytic activity, and on steric and electronic properties.

\section{Computational Details}

Calculations were carried out using the Archie-WeSt High Performance Computer and Gaussian 09 Rev. D.01. ${ }^{[33]}$ The B3LYP functional and 6-31G(d) basis set were used throughout. All calculations were carried out in the gas phase without a solvent model. Geometry optimisations were carried out without symmetry constraints, and the nature of each stationary point was verified using frequency calculations.

\section{Experimental Section}

General. Unless otherwise stated, all materials were obtained from commercial sources and used as supplied. Compound $\mathbf{5}$ and IPaul. $\mathrm{HCl}$ (1) were prepared according to literature procedures. ${ }^{[10]}$ Anhydrous solvents were obtained from an Innovative Technologies PureSolv solvent drying system. NMR analyses were conducted using a Bruker AV3-400 spectrometer equipped with a liquid nitrogen cryoprobe. ${ }^{1} \mathrm{H}$ NMR spectra are referenced to residual solvent signals, and ${ }^{13} \mathrm{C}\left\{{ }^{1} \mathrm{H}\right\}$ NMR spectra - which are typically from $J$-modulated spin echo (JMOD) experiments to differentiate quaternary, $\mathrm{CH}, \mathrm{CH}_{2}$, and $\mathrm{CH}_{3}$ signals - are referenced to solvent signals. ${ }^{[34]} 2 \mathrm{D}$ NMR experiments such as $\left[{ }^{1} \mathrm{H},{ }^{1} \mathrm{H}\right]$ COSY, $\left[{ }^{1} \mathrm{H},{ }^{13} \mathrm{C}\right] \mathrm{HSQC}$, and $\left[{ }^{1} \mathrm{H},{ }^{13} \mathrm{C}\right] \mathrm{HMBC}$ were used to assign signals, as appropriate. GC-MS analyses were carried out on an Agilent 7890A instrument coupled to an Agilent 5975C mass spectrometer with electron impact ionisation. IR spectra were acquired using a Shmadzu IRAffinity-1 spectrometer. LC-MS analyses were carried out using an Agilent 1200 HPLC coupled to an Agilent 6130 mass spectrometer operating in ACPI/ESI mode. High resolution mass spectrometry data were acquired using an LTQ Orbitrap XL instrument at the University of Swansea. Elemental analyses were conducted either at Strathclyde, using a Perkin Elmer 2400 Series II instrument, or at London Metropolitan University.

\section{$N, N$ '-bis(2-diphenylmethyl-4,6-dimethylphenyl)-ethane-1,2-diamine}

(7). A round-bottom flask was charged with $N, N^{\prime}$-bis(2-diphenylmethyl4,6-dimethylphenyl)-ethane-1,2-diimine (5) (250 mg, $0.45 \mathrm{mmmol}, 1.0$ equiv.) and anhydrous toluene $(25 \mathrm{~mL})$. The flask was purged with nitrogen for 20 minutes, and then sodium bis(methoxyethoxy)aluminium dihydride (Red-Al, 6) (5 mL, 1.35 mmol, 3.0 equiv.) was added slowly, resulting in the formation of gas. The reaction was stirred under a nitrogen atmosphere for 2 h. $5 \% w / w \mathrm{NaOH}$ aqueous solution was added, dropwise at first, to quench the reaction, and then the reaction was stirred for $20 \mathrm{~min}$. The organic layer was washed with water $(3 \times 70 \mathrm{~mL})$, with the final wash having a neutral $\mathrm{pH}$. The organic layer was washed with brine $(2 \times 40 \mathrm{~mL})$, dried on $\mathrm{MgSO}_{4}$, and concentrated to yield a yellow powder. $160 \mathrm{mg}, 0.26 \mathrm{mmol}, 68 \%$. ${ }^{1} \mathrm{H}$ NMR $\left(\mathrm{CDCl}_{3}, 400 \mathrm{MHz}\right): \delta_{\mathrm{H}}$ 7.32-7.17 (m, 12H, Ar CH), 7.07 (app. d, 8H, Ar CH), 6.91 (s, 2H, $\mathrm{Ar} \mathrm{CH}$ ), 6.51 (s, 2H, Ar CH), 5.76 (s, 2H, $\mathrm{CHPh}_{2}$ ), 3.03 (br. s, 2H, NH), 2.75 (s, $\left.4 \mathrm{H}, \mathrm{N}\left(\mathrm{CH}_{2}\right)_{2} \mathrm{~N}\right), 2.22\left(\mathrm{~s}, 6 \mathrm{H}, \mathrm{CH}_{3}\right), 2.19\left(\mathrm{~s}, 6 \mathrm{H}, \mathrm{CH}_{3}\right) .{ }^{13} \mathrm{C}\left\{{ }^{1} \mathrm{H}\right\} \quad \mathrm{NMR}$ $\left(\mathrm{CDCl}_{3}, 101 \mathrm{MHz}\right)$ : $\delta \mathrm{c} 143.4(\mathrm{Ar} \mathrm{C}), 143.2(\mathrm{Ar} \mathrm{C}), 137.0(\mathrm{Ar} \mathrm{C}), 131.8(\mathrm{Ar}$ C), $131.7(\mathrm{Ar} \mathrm{C}), 130.4(\mathrm{Ar} \mathrm{CH}), 129.7(\mathrm{Ar} \mathrm{CH}), 129.1(\mathrm{Ar} \mathrm{CH}), 128.4(\mathrm{Ar}$ $\mathrm{CH}), 126.4(\mathrm{Ar} \mathrm{CH}), 51.9\left(\mathrm{CHPh}_{2}\right), 49.5\left(\mathrm{~N}\left(\mathrm{CH}_{2}\right)_{2} \mathrm{~N}\right), 21.1\left(\mathrm{CH}_{3}\right), 18.7$ $\left(\mathrm{CH}_{3}\right)$. M. P. $143-145{ }^{\circ} \mathrm{C}$. HRMS. $\mathrm{m} / \mathrm{z}$ calc'd for $\mathrm{C}_{44} \mathrm{H}_{45} \mathrm{~N}_{2}[\mathrm{M}+\mathrm{H}]+$ 601.3577 ; found 601.3566 .

1,3-bis(2-diphenylmethyl-4,6-dimethylphenyl)-4,5-dihydroimidazolium chloride (4). A microwave vial equipped with a stir bar was charged with 7 (2.04 g, $3.4 \mathrm{mmol}, 1.0$ equiv.), triethyl orthoformate $(700 \mu \mathrm{L}, 624$ $\mathrm{mg}, 4.2 \mathrm{mmol}, 1.2$ equiv.), $\mathrm{HCl}$ in 1,4-dioxane $\left(1 \mathrm{~mL}\right.$ of a $4 \mathrm{~mol} \mathrm{~L}^{-1}$ solution, $4 \mathrm{mmol}, 1.2$ equiv.), and 1,4-dioxane (15 mL). The reaction was heated in the microwave at $145^{\circ} \mathrm{C}$ for $1 \mathrm{~h}$. Hexane $(6 \mathrm{~mL})$ was added to the resulting thick suspension, and the product was collected by filtration as a white powder. $1.90 \mathrm{~g}, 2.9 \mathrm{mmol}, 86 \%$. The product is obtained as a 2:1 mixture of rotamers (see text). Rotamer $\boldsymbol{A}:{ }^{1} \mathbf{H}$ NMR $\left(\mathrm{CDCl}_{3}, 400\right.$ $\mathrm{MHz}): \delta_{\mathrm{H}} 9.27(\mathrm{~s}, 1 \mathrm{H}, \mathrm{N}(\mathrm{CH}) \mathrm{N}), 7.37-7.05(\mathrm{~m}, 2 \mathrm{H}, \mathrm{Ar} \mathrm{CH}), 7.00(\mathrm{~s}, 2 \mathrm{H}$, $\operatorname{Ar} \mathrm{CH}), 6.55$ (s, 2H, Ar CH), 5.85 (s, 2H, $\left.\mathrm{CHPh}_{2}\right), 4.03-3.88(\mathrm{~m}, 2 \mathrm{H}$, $\left.\mathrm{N}\left(\mathrm{CH}_{2}\right)_{2} \mathrm{~N}\right), 3.61-3.45\left(\mathrm{~m}, 2 \mathrm{H}, \mathrm{N}\left(\mathrm{CH}_{2}\right)_{2} \mathrm{~N}\right), 2.35\left(\mathrm{~s}, 3 \mathrm{H}, \mathrm{CH}_{3}\right), 2.20(\mathrm{~s}, 3 \mathrm{H}$, $\left.\mathrm{CH}_{3}\right)$. Rotamer B: ${ }^{1} \mathrm{H}$ NMR $\left(\mathrm{CDCl}_{3}, 400 \mathrm{MHz}\right): \delta_{\mathrm{H}} 9.67(\mathrm{~s}, 1 \mathrm{H}, \mathrm{N}(\mathrm{CH}) \mathrm{N})$, 7.37-7.05 (m, 20H, Ar CH), 7.02 (s, 2H, Ar CH), 6.58 (s, 2H, Ar CH), 5.63 $\left(\mathrm{s}, 2 \mathrm{H}, \mathrm{CHPh}_{2}\right), 4.42-4.31\left(\mathrm{~m}, 2 \mathrm{H}, \mathrm{N}\left(\mathrm{CH}_{2}\right)_{2} \mathrm{~N}\right), 3.23-3.13(\mathrm{~m}, 2 \mathrm{H}$, $\left.\mathrm{N}\left(\mathrm{CH}_{2}\right)_{2} \mathrm{~N}\right), 2.47\left(\mathrm{~s}, 3 \mathrm{H}, \mathrm{CH}_{3}\right), 2.20\left(\mathrm{~s}, 3 \mathrm{H}, \mathrm{CH}_{3}\right)$. Both rotamers ${ }^{13} \mathrm{C}\left\{{ }^{1} \mathrm{H}\right\}$ NMR $\left(\mathrm{CDCl}_{3}, 101 \mathrm{MHz}\right)$ : $\delta_{\mathrm{c}} 160.9(\mathrm{~N}(\mathrm{CH}) \mathrm{N}$, rot. A), $160.8(\mathrm{~N}(\mathrm{CH}) \mathrm{N}$, rot. B), $142.8(\operatorname{Ar~C}), 142.6(\operatorname{Ar~C}), 142.3(\operatorname{Ar~C}), 142.2(\operatorname{Ar~C}), 141.4(\operatorname{Ar~C})$, $141.2(\operatorname{Ar} C), 140.7(\operatorname{Ar~C}), 140.6(\operatorname{Ar~C}), 135.9(\operatorname{Ar~C}), 135.6(\operatorname{Ar~C})$, 131.3 (Ar CH), $131.0(\operatorname{Ar~CH}), 130.4(\operatorname{Ar~C}), 130.3(\operatorname{Ar~C}), 130.1(\mathrm{Ar} \mathrm{CH})$, 130.0 ( $\mathrm{Ar} \mathrm{CH}), 129.8(\mathrm{Ar} \mathrm{CH}), 129.7(\mathrm{Ar} \mathrm{CH}), 129.5(\mathrm{Ar} \mathrm{CH}), 129.1(\mathrm{Ar}$ $\mathrm{CH}), 128.9$ ( $\mathrm{Ar} \mathrm{CH}), 128.7$ ( $\mathrm{Ar} \mathrm{CH}), 127.5(\mathrm{Ar} \mathrm{CH}), 127.3(\mathrm{Ar} \mathrm{CH}), 127.1$ $(\mathrm{Ar} \mathrm{CH}), 126.9(\mathrm{Ar} \mathrm{CH}), 52.3\left(\mathrm{~N}\left(\mathrm{CH}_{2}\right)_{2} \mathrm{~N}\right.$, rot. B), $52.0\left(\mathrm{~N}\left(\mathrm{CH}_{2}\right)_{2} \mathrm{~N}\right.$, rot. A), $51.8\left(\mathrm{CHPh}_{2}\right.$, rot. A), $51.7\left(\mathrm{CHPh}_{2}\right.$, rot. B), $21.5\left(\mathrm{CH}_{3}\right), 18.8\left(\mathrm{CH}_{3}\right), 18.5$ $\left(\mathrm{CH}_{3}\right)$. Elemental Analysis calc'd (\%) for $\mathrm{C}_{45} \mathrm{H}_{43} \mathrm{CIN}_{2}$ : C 83.5, H 6.7, N 4.3; found: C 82.9, H 6.6, N 4.3. LRMS (LCMS, $\left.\mathrm{MeCN} / \mathrm{H}_{2} \mathrm{O}, \mathrm{ESI}+\mathrm{ACPI}\right)$ $\mathrm{m} / \mathrm{z}$ : 611.4, 612.4; HRMS (LTQ, Orbitrap XL, DCM/MeOH) m/z: 611.3403. $\mathrm{C}_{45} \mathrm{H}_{43} \mathrm{~N}_{2}$ requires 611.3421 .

1,3-bis(2-diphenylmethyl-4,6-dimethylphenyl)-4,5-dihydroimidazol-2yl)silver(I) chloride (8). A microwave vial was equipped with a stirrer bar and charged with 4 ( $80.7 \mathrm{mg}, 0.125 \mathrm{mmol}, 1.0$ equiv.), $\mathrm{AgNO}_{3}$ (28.6 mg, $0.168 \mathrm{mmol}, 1.3$ equiv.), $\mathrm{K}_{2} \mathrm{CO}_{3}$ (106.2 $\mathrm{mg}, 0.768 \mathrm{mmol}, 6.1$ equiv.), and DCM $(2 \mathrm{~mL})$. The reaction was placed under a nitrogen atmosphere, wrapped in aluminium foil and stirred for $36 \mathrm{~h}$. The crude reaction mixture was filtered through silica, the pad was washed with DCM, and the resulting solution was concentrated under reduced pressure. The addition of pentane led to the precipitation of the product as a white solid. $69.0 \mathrm{mg}, 0.092 \mathrm{mmol}, 73 \%$. The product is obtained as a $5: 4$ mixture of rotamers (see text). ${ }^{1} \mathrm{H}$ NMR $\left(\mathrm{CDCl}_{3}, 400 \mathrm{MHz}\right)$ : $\delta_{\mathrm{H}} 7.40-6.97(\mathrm{~m}, 22 \mathrm{H}, \mathrm{Ar}$ $\mathrm{CH}), 6.68(\mathrm{~d}, J=1.4 \mathrm{~Hz}, 2 \mathrm{H}, \mathrm{Ar} \mathrm{CH}$, rot. B), 6.61 (d, $J=1.3 \mathrm{~Hz}, 2 \mathrm{H}, \mathrm{Ar}$ $\mathrm{CH}$, rot. A), $5.88\left(\mathrm{~s}, 2 \mathrm{H}, \mathrm{CHPh}_{2}\right.$, rot. A), 5.76 (s, 2H, $\mathrm{CHPh}_{2}$, rot. B), 3.70$3.61\left(\mathrm{~m}, 2 \mathrm{H}, \mathrm{N}\left(\mathrm{CH}_{2}\right)_{2} \mathrm{~N}\right.$, rot. B), 3.49-3.32 (m, $2 \mathrm{H}, \mathrm{N}\left(\mathrm{CH}_{2}\right)_{2} \mathrm{~N}$, rot. A), 3.23$3.13\left(\mathrm{~m}, 2 \mathrm{H}, \mathrm{N}\left(\mathrm{CH}_{2}\right)_{2} \mathrm{~N}\right.$, rot. B), 2.99-2.83 (m, $2 \mathrm{H}, \mathrm{N}\left(\mathrm{CH}_{2}\right)_{2} \mathrm{~N}$, rot. A), 2.31 $\left(\mathrm{s}, 6 \mathrm{H}, \mathrm{CH}_{3}\right), 2.29\left(\mathrm{~s}, 6 \mathrm{H}, \mathrm{CH}_{3}\right), 2.26\left(\mathrm{~s}, 6 \mathrm{H}, \mathrm{CH}_{3}\right) .{ }^{13} \mathrm{C}\left\{{ }^{1} \mathrm{H}\right\} \mathrm{NMR}\left(\mathrm{CDCl}_{3}\right.$, $101 \mathrm{MHz}$ ): $\delta_{\mathrm{C}} 210.1$ (d, JC-Ag $\left.=17.5 \mathrm{~Hz}, \mathrm{C}-\mathrm{Ag}\right), 207.7$ (d, JC-Ag $=16.1 \mathrm{~Hz}$, C-Ag), 143.5 ( $\operatorname{ArC}$ ), $143.3(\operatorname{ArC} C), 142.68(\operatorname{Ar~C}), 142.65(\operatorname{ArC}$ ), $142.0(\operatorname{Ar}$ C), $141.8(\operatorname{Ar~C}), 139.1(\operatorname{Ar~C}), 139.0(\operatorname{Ar~C}), 135.8(\operatorname{Ar~C}), 135.2(\operatorname{Ar~C})$, 130.9 (Ar CH), 130.0 ( $\mathrm{Ar} \mathrm{CH}), 129.7(\mathrm{Ar} \mathrm{CH}), 129.6(\mathrm{Ar} \mathrm{CH}), 128.92(\mathrm{Ar}$ $\mathrm{CH}), 128.86(\mathrm{Ar} \mathrm{CH}), 128.79(\mathrm{Ar} \mathrm{CH}), 128.76(\mathrm{Ar} \mathrm{CH}), 127.01(\mathrm{Ar} \mathrm{CH})$, $126.96(\mathrm{Ar} \mathrm{CH}), 126.8(\mathrm{Ar} \mathrm{CH}), 52.0\left(\mathrm{CHPh}_{2}\right), 51.65\left(\mathrm{~N}\left(\mathrm{CH}_{2}\right)_{2} \mathrm{~N}\right), 51.57$ $\left(\mathrm{N}\left(\mathrm{CH}_{2}\right)_{2} \mathrm{~N}\right), 51.5\left(\mathrm{CHPh}_{2}\right), 51.2\left(\mathrm{~N}\left(\mathrm{CH}_{2}\right)_{2} \mathrm{~N}\right), 51.1\left(\mathrm{~N}\left(\mathrm{CH}_{2}\right)_{2} \mathrm{~N}\right), 21.5\left(\mathrm{CH}_{3}\right)$, 
$18.45\left(\mathrm{CH}_{3}\right), \quad 18.37 \quad\left(\mathrm{CH}_{3}\right)$. Elemental Analysis calc'd (\%) for $\mathrm{C}_{45} \mathrm{H}_{43} \mathrm{ClAgN}_{2}$ : C 71.6, H 5.7, N 3.7; found: C 71.1, H 5.6, N 3.7.

(1,3-bis(2-diphenylmethyl-4,6-dimethylphenyl)-4,5-dihydroimidazol2-yl)copper(I) chloride (9). A microwave vial was equipped with a stirrer bar and charged with 4 (73.1 mg, $0.113 \mathrm{mmol}, 1.0$ equiv.), $\mathrm{CuCl}$ (50.6 mg $0.511 \mathrm{mmol}, 4.5$ equiv.), $\mathrm{K}_{2} \mathrm{CO}_{3}(114.3 \mathrm{mg}, 0.827 \mathrm{mmol}, 7.3$ equiv.) and acetone $(3 \mathrm{~mL})$. The reaction was placed under a nitrogen atmosphere and heated to $60{ }^{\circ} \mathrm{C}$ for $20 \mathrm{~h}$. The crude reaction mixture was filtered through a pad of silica, which washed with DCM. The solvent was concentrated under reduced pressure and the product was precipitated by addition of pentane to yield a white solid. $73.9 \mathrm{mg}, 0.104 \mathrm{mmol}, 92 \%$. The product is obtained as a 4:3 mixture of rotamers (see text). ${ }^{1} \mathrm{H}$ NMR $\left(\mathrm{CDCl}_{3}, 400 \mathrm{MHz}\right): \delta_{\mathrm{H}} 7.38-7.09(\mathrm{~m}, 20 \mathrm{H}, \mathrm{Ar} \mathrm{CH}), 7.03(\mathrm{~s}, 2 \mathrm{H}, \mathrm{Ar} \mathrm{CH})$, $6.69(\mathrm{~d}, J=1.1 \mathrm{~Hz}, 2 \mathrm{H}, \mathrm{Ar} \mathrm{CH}$, rot. A), $6.61(\mathrm{~d}, J=1.3 \mathrm{~Hz}, 2 \mathrm{H}, \mathrm{ArCH}$, rot. B), $5.95\left(\mathrm{~s}, 2 \mathrm{H}, \mathrm{CHPh}_{2}\right.$, rot. B), $5.87\left(\mathrm{~s}, 2 \mathrm{H}, \mathrm{CHPh}_{2}\right.$, rot. A), 3.61-3.52 (m, $2 \mathrm{H}, \mathrm{N}\left(\mathrm{CH}_{2}\right)_{2} \mathrm{~N}$, rot. A), 3.38-3.24 (m, $2 \mathrm{H}, \mathrm{N}\left(\mathrm{CH}_{2}\right)_{2} \mathrm{~N}$, rot. B), 3.08-2.99 (m, $2 \mathrm{H}, \mathrm{N}\left(\mathrm{CH}_{2}\right)_{2} \mathrm{~N}$, rot. A), 2.83-2.69 (m, $2 \mathrm{H}, \mathrm{N}\left(\mathrm{CH}_{2}\right)_{2} \mathrm{~N}$, rot. B), 2.34 (s, $3 \mathrm{H}$ $\left.\mathrm{CH}_{3}\right), 2.33\left(\mathrm{~s}, 3 \mathrm{H}, \mathrm{CH}_{3}\right), 2.26\left(\mathrm{~s}, 3 \mathrm{H}, \mathrm{CH}_{3}\right) .{ }^{13} \mathrm{C}\left\{{ }^{1} \mathrm{H}\right\}$ NMR $\left(\mathrm{CDCl}_{3}, 101\right.$ $\mathrm{MHz}$ ): סc 203.9 (C-Cu, rot. A), 203.8 (C-Cu, rot. B), 143.5 ( $\mathrm{Ar} \mathrm{C}), 143.3$ ( $\operatorname{Ar~C}), 143.0(\operatorname{Ar~C}), 142.9(\operatorname{Ar~C}), 142.1(\operatorname{Ar~C}), 141.9(\operatorname{Ar~C}), 138.9(\operatorname{Ar}$ C), 138.8 ( $\operatorname{Ar~C}$ ), 135.8 ( $\operatorname{ArC}$ ), 135.11 ( $\operatorname{ArC}$ ), 135.07 ( $\mathrm{Ar} \mathrm{C}), 130.78(\mathrm{Ar}$ $\mathrm{CH}), 130.75(\mathrm{Ar} \mathrm{CH}), 129.9(\mathrm{Ar} \mathrm{CH}), 129.81(\mathrm{Ar} \mathrm{CH}), 129.77(\mathrm{Ar} \mathrm{CH})$, 129.68 ( $\mathrm{Ar} \mathrm{CH}), 129.67(\mathrm{Ar} \mathrm{CH}), 128.75(\mathrm{Ar} \mathrm{CH}), 128.73(\mathrm{Ar} \mathrm{CH}), 127.0$ $(\mathrm{Ar} \mathrm{CH}), 126.9(\mathrm{Ar} \mathrm{CH}), 126.7(\mathrm{Ar} \mathrm{CH}), 52.0\left(\mathrm{CHPh}_{2}\right.$, rot. B), $51.6\left(\mathrm{CHPh}_{2}\right.$

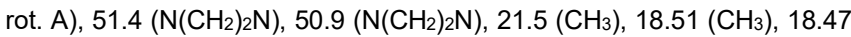
$\left(\mathrm{CH}_{3}\right)$. Elemental Analysis calc'd (\%) for $\mathrm{C}_{45} \mathrm{H}_{43} \mathrm{ClCuN}_{2}$ : C 76.0, $\mathrm{H}$ 6.1, N 3.9; found: C 75.4, H 6.0, N 3.9.

(1,3-bis(2-diphenylmethyl-4,6-dimethylphenyl)-4,5-dihydroimidazol2-yl)( $\eta^{2}, \eta^{2}-1,5$-cyclooctadienyl)iridium(I) chloride (10). A vial equipped with a stirrer bar and charged with $4(98.2 \mathrm{mg}, 0.152 \mathrm{mmol}, 1.0$ equiv.), $[\operatorname{lr}(\mu-\mathrm{Cl})(\mathrm{cod})]_{2}\left(52.5 \mathrm{mg}, 0.078 \mathrm{mmol}, 0.5\right.$ equiv.), $\mathrm{K}_{2} \mathrm{CO}_{3}(237.7 \mathrm{mg}, 1.72$ mmol, 11 equiv.) and acetone ( $3 \mathrm{~mL})$ was placed under a nitrogen atmosphere. The reaction was stirred at $60^{\circ} \mathrm{C}$ for $24 \mathrm{~h}$. The solvent was removed under reduced pressure, and the residue was taken up in the minimum amount of DCM and filtered through silica. The pad was washed with DCM until the filtrate was clear. The DCM solution was concentrated under reduced pressure, and pentane was added to precipitate the product as a yellow solid. $96.3 \mathrm{mg}, 0.102 \mathrm{mmol}, 67 \%$. The product is obtained as a $5: 3$ mixture of rotamers (see text); the presence of these rotamers, and the overlap between COD, methyl, and backbone protons makes the proton NMR spectrum rather complex and it is difficult to assign signals to specific rotamers. ${ }^{1} \mathrm{H}$ NMR $\left(\mathrm{CDCl}_{3}, 400 \mathrm{MHz}\right): \delta_{\mathrm{H}}$ 4.47 (s, 1H, CHPh ${ }_{2}$ ), 7.46-7.37 (m, $\left.\mathrm{Ar} \mathrm{CH}\right), 7.23$ (s, 2H, $\left.\mathrm{CHPh}_{2}\right), 7.10-$ 6.99 (m, Ar CH), 6.67 (s, 2H, $\mathrm{Ar} \mathrm{CH}), 6.62(\mathrm{~d}, J=1.8 \mathrm{~Hz}, \mathrm{ArCH}), 6.42(\mathrm{~s}$, $\left.1 \mathrm{H}, \mathrm{CHPh}_{2}\right), 4.74-4.64(\mathrm{~m}, 2 \mathrm{H}, \mathrm{COD} \mathrm{CH}$, rot. B), 4.55-4.45 (m, 2H, COD $\mathrm{CH}$, rot. A), 3.48-3.39 (m, 2H, COD CH, rot B.), 3.18-3.10 (m, 2H, COD $\mathrm{CH}$, rot A.), 3.07-3.01 (m, $\left.2 \mathrm{H}, \mathrm{N}\left(\mathrm{CH}_{2}\right)_{2} \mathrm{~N}\right), 2.97-2.79\left(\mathrm{~m}, 4 \mathrm{H}, \mathrm{N}\left(\mathrm{CH}_{2}\right)_{2} \mathrm{~N}\right)$, $2.52\left(\mathrm{CH}_{3}\right), 2.28\left(\mathrm{CH}_{3}\right), 2.27\left(\mathrm{CH}_{3}\right), 2.25-2.08\left(\mathrm{~m}, 2 \mathrm{H}, \mathrm{N}\left(\mathrm{CH}_{2}\right)_{2} \mathrm{~N}\right), 2.21-$ $1.14(\mathrm{~m}, \mathrm{COD} \mathrm{CH}) .{ }^{13} \mathrm{C}\left\{{ }^{1} \mathrm{H}\right\}$ NMR $\left(\mathrm{CDCl}_{3}, 101 \mathrm{MHz}\right): \delta c 210.4$ (C-Ir, rot. B), 204.8 (C-Ir, rot. A), 145.31 ( $\operatorname{Ar~C}), 145.26(\operatorname{Ar~C}), 144.7(\operatorname{Ar~C}), 144.6$ ( $\operatorname{ArC}$ ), 144.38 (Ar C), 144.34 ( $\operatorname{ArC}$ ), 144.2 (Ar C), 143.6 ( $\operatorname{Ar~C}), 142.3(\operatorname{Ar}$ C), $138.4(\operatorname{Ar} C), 137.59(\operatorname{Ar~C}), 137.56(\operatorname{Ar~C}), 137.44(\operatorname{Ar~C}), 137.35(\operatorname{Ar}$ C), $137.2(\mathrm{Ar} \mathrm{C}), 137.1(\mathrm{ArC}), 135.6(\mathrm{ArC}), 135.5(\mathrm{Ar} \mathrm{C}), 131.0(\mathrm{Ar} \mathrm{CH})$, 130.6 ( $\mathrm{Ar} \mathrm{CH}), 130.5$ ( $\mathrm{Ar} \mathrm{CH}), 130.3(\mathrm{Ar} \mathrm{CH}), 130.14(\mathrm{Ar} \mathrm{CH}), 130.08(\mathrm{Ar}$ $\mathrm{CH}), 130.0(\mathrm{Ar} \mathrm{CH}), 129.9(\mathrm{Ar} \mathrm{CH}), 129.7(\mathrm{Ar} \mathrm{CH}), 128.8(\mathrm{Ar} \mathrm{CH}), 128.7$ ( $\mathrm{Ar} \mathrm{CH}), 128.4(\mathrm{Ar} \mathrm{CH}), 128.2(\mathrm{Ar} \mathrm{CH}), 127.9(\mathrm{Ar} \mathrm{CH}), 127.8(\mathrm{Ar} \mathrm{CH})$, 127.7 ( $\mathrm{Ar} \mathrm{CH}), 126.7(\mathrm{Ar} \mathrm{CH}), 126.4(\mathrm{Ar} \mathrm{CH}), 126.3(\mathrm{Ar} \mathrm{CH}), 126.1(\mathrm{Ar}$ $\mathrm{CH}), 125.9(\mathrm{Ar} \mathrm{CH}), 125.7(\mathrm{Ar} \mathrm{CH}), 85.3(\mathrm{COD} \mathrm{CH}), 85.1(\mathrm{COD} \mathrm{CH})$,

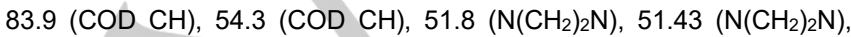

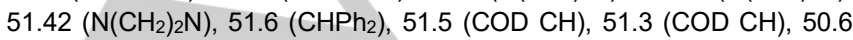
$\left.\left(\mathrm{CHPh}_{2}\right), 50.1\left(\mathrm{CHPh}_{2}\right), 34.4(\mathrm{COD} \mathrm{CH})_{2}\right), 33.5(\mathrm{COD} \mathrm{CH}), 32.8(\mathrm{COD}$ $\left.\mathrm{CH}_{2}\right), 29.6(\mathrm{COD} \mathrm{CH}), 28.7(\mathrm{COD} \mathrm{CH}), 27.5\left(\mathrm{COD} \mathrm{CH}_{2}\right), 21.49\left(\mathrm{CH}_{3}\right)$,
$21.47\left(\mathrm{CH}_{3}\right), 21.45\left(\mathrm{CH}_{3}\right), 21.0\left(\mathrm{CH}_{3}\right), 19.4\left(\mathrm{CH}_{3}\right), 19.0\left(\mathrm{CH}_{3}\right)$. Elemental Analysis calc'd (\%) for $\mathrm{C}_{53} \mathrm{H}_{54} \mathrm{ClllN}_{2}$ : C 67.2, H 5.8, N 3.0; found: C 65.3, H 6.2, N 2.7. Despite repeated attempts, satisfactory results could not be obtained for this compound, perhaps as a result of incomplete combustion.

(1,3-bis(2-diphenylmethyl-4,6-dimethylphenyl)-4,5-dihydroimidazol2-yl)( $\eta^{5}$-cyclopentadienyl)nickel(II) chloride (11). A vial was equipped with a stirrer bar and charged with $4(131.6 \mathrm{mg}, 0.204 \mathrm{mmol}, 1.0$ equiv.) and [ $\mathrm{NiCp}_{2}$ ] $(71.3 \mathrm{mg}, 0.377 \mathrm{mmol}, 1.9$ equiv.). The vial was evacuated, backfilled with argon, and charged with anhydrous THF $(2 \mathrm{~mL})$. The reaction was stirred at $80{ }^{\circ} \mathrm{C}$ for $24 \mathrm{~h}$, during which time the reaction turned from green to purple/red. The solvents were removed in vacuo and the residue was taken up in DCM, and purified by chromatography on silica gel using DCM; the initial green and yellow fractions were discarded, and the red/pink fraction was collected. The DCM solution was concentrated under reduced pressure, and pentane was added to precipitate the product as a pink solid. $90.7 \mathrm{mg}, 0.118 \mathrm{mmol}, 58 \%$. The product is obtained as a ca. 5:4 mixture of rotamers which are difficult to distinguish by NMR spectroscopy (see text); data here are reported for both rotamers. ${ }^{1} \mathrm{H}$ NMR $\left(\mathrm{CDCl}_{3}, 400 \mathrm{MHz}\right): \delta_{\mathrm{H}} 7.54-7.01(\mathrm{~m}, 2 \mathrm{H}, \mathrm{Ar} \mathrm{CH})$ $7.14\left(\mathrm{~s}, 2 \mathrm{H}, \mathrm{CHPh}_{2}\right), 6.77$ (s, $\left.4 \mathrm{H}, \mathrm{Ar} \mathrm{CH}\right), 4.77$ (s, 5H, Cp CH, rot. A), 4.64 (s, $5 \mathrm{H}, \mathrm{Cp} \mathrm{CH}$, rot. B), 3.02-2.93 (m, $2 \mathrm{H}, \mathrm{N}\left(\mathrm{CH}_{2}\right)_{2} \mathrm{~N}$, rot. B), 2.88$2.78\left(\mathrm{~m}, 2 \mathrm{H}, \mathrm{N}\left(\mathrm{CH}_{2}\right)_{2} \mathrm{~N}\right.$, rot. A), $2.32\left(\mathrm{~s}, 3 \mathrm{H}, \mathrm{CH}_{3}\right), 2.31\left(\mathrm{~s}, 3 \mathrm{H}, \mathrm{CH}_{3}\right), 2.30$ (s, $\left.3 \mathrm{H}, \mathrm{CH}_{3}\right), 2.20-2.12\left(\mathrm{~m}, 2 \mathrm{H}, \mathrm{N}\left(\mathrm{CH}_{2}\right)_{2} \mathrm{~N}\right.$, rot. A), $2.08\left(\mathrm{~s}, 3 \mathrm{H}, \mathrm{CH}_{3}\right)$, 2.06-1.99 (m, 2H, N( $\left.\mathrm{CH}_{2}\right)_{2} \mathrm{~N}$, rot. B). ${ }^{13} \mathrm{C}\left\{{ }^{1} \mathrm{H}\right\} \mathrm{NMR}\left(\mathrm{CDCl}_{3}, 101 \mathrm{MHz}\right): \delta \mathrm{c}$ 203.2 (C-Ni), 199.7 (C-Ni), 145.3 ( $(\operatorname{Cr}$ C), 145.0 ( $(\operatorname{Ar~C}), 144.4$ (Ar C), 144.3 ( $\operatorname{ArC}), 143.6(\operatorname{Ar~C}), 143.5(\operatorname{Ar~C}), 138.0(\operatorname{Ar~C}), 137.9(\operatorname{Ar~C})$, 137.6 ( $\operatorname{ArC}$ ), $137.0(\operatorname{Ar~C}), 135.6(\operatorname{Ar~C}), 130.7(\operatorname{Ar~CH}), 130.6(\mathrm{Ar} \mathrm{CH})$, 130.3 ( $\mathrm{Ar} \mathrm{CH}), 130.1(\mathrm{Ar} \mathrm{CH}), 129.9(\mathrm{Ar} \mathrm{CH}), 129.5(\mathrm{Ar} \mathrm{CH}), 128.52(\mathrm{Ar}$ $\mathrm{CH}), 128.46(\mathrm{Ar} \mathrm{CH}), 128.3(\mathrm{Ar} \mathrm{CH}), 128.0(\mathrm{Ar} \mathrm{CH}), 126.7(\mathrm{Ar} \mathrm{CH}), 126.4$ ( $\mathrm{Ar} \mathrm{CH}), 126.2(\mathrm{Ar} \mathrm{CH}), 126.0(\mathrm{Ar} \mathrm{CH}), 93.3(\mathrm{Cp} \mathrm{CH}), 92.7(\mathrm{Cp} \mathrm{CH}), 51.6$ $\left.\left(\mathrm{CHPh}_{2}\right), 51.2\left(\mathrm{~N}\left(\mathrm{CH}_{2}\right)_{2} \mathrm{~N}\right), 50.6\left(\mathrm{CHPh}_{2}\right), 50.5\left(\mathrm{~N}^{\left(\mathrm{CH}_{2}\right)}\right)_{2} \mathrm{~N}\right), 21.6\left(\mathrm{CH}_{3}\right)$, $19.5\left(\mathrm{CH}_{3}\right), 18.5\left(\mathrm{CH}_{3}\right)$. Elemental Analysis calc'd (\%) for $\mathrm{C}_{50} \mathrm{H}_{48} \mathrm{CINiN}_{2}$ : C 78.0, H 6.2, N 3.6; found: C 77.7, H 6.3, N 3.5.

(1,3-bis(2-diphenylmethyl-4,6-dimethylphenyl)-4,5-imidazol-2yl)dicarbonyliridium(I) chloride (12). $10(39.1 \mathrm{mg}, 0.041 \mathrm{mmol})$ was dissolved in chloroform $(2 \mathrm{~mL})$ and carbon monoxide was bubbled through the solution for 5 minutes. The colour of the solution changed from dark yellow to pale yellow. The vial was then sealed and kept under a carbon monoxide atmosphere using a balloon filled with $\mathrm{CO}$. The reaction was stirred for $3 \mathrm{~h}$ at room temperature. Diethyl ether was added to precipitate the product, which was washed with pentane to yield a pale yellow solid. $20.1 \mathrm{mg}, 0.022 \mathrm{mmol}, 55 \%$. The product is obtained as a ca. 1:1 mixture of rotamers (see text). Rotamer $\boldsymbol{A}{ }^{1} \mathbf{H}$ NMR $\left(\mathrm{CDCl}_{3}, 400\right.$ $\mathrm{MHz}): \delta_{\mathrm{H}} 7.65$ (d, 4H, ArH), 7.25-6.95 (m, 20H, ArH), $6.81\left(\mathrm{~s}, 2 \mathrm{H}, \mathrm{CHPh}_{2}\right)$ 2.63-2.57 (m, 2H, m, CH 2$), 2.25\left(\mathrm{~s}, 6 \mathrm{H}, \mathrm{CH}_{3}\right) 2.11\left(\mathrm{~s}, 2 \mathrm{H}, \mathrm{CH}_{2}\right), 1.86(\mathrm{~s}$, $\left.6 \mathrm{H}, \mathrm{CH}_{3}\right)$. Rotamer $\boldsymbol{B}^{1}{ }^{\mathrm{H}}$ NMR $\left(\mathrm{CDCl}_{3}, 400 \mathrm{MHz}\right): \delta_{\mathrm{H}} 7.71(\mathrm{~d}, 4 \mathrm{H}, \mathrm{ArH})$, 7.25-6.95 (m, 20H, ArH), $6.81\left(\mathrm{~s}, 2 \mathrm{H}, \mathrm{CHPh}_{2}\right) .2 .70\left(\mathrm{~s}, 2 \mathrm{H}, \mathrm{CH}_{2}\right) 2.41(\mathrm{~s}$, $\left.6 \mathrm{H}, \mathrm{CH}_{3}\right), 2.28\left(\mathrm{~s}, 2 \mathrm{H}, \mathrm{CH}_{2}\right.$ ), 1.89 (s, $6 \mathrm{H}, \mathrm{CH}_{3}$ ). IR (DCM solution): 2064.7, $1981.2 \mathrm{~cm}^{-1}$. Poor solubility in $\mathrm{CDCl}_{3}, \mathrm{C}_{6} \mathrm{D}_{6}$, and THF-d $d_{8}$ precluded ${ }^{13} \mathrm{C}\left\{{ }^{1} \mathrm{H}\right\} \quad \mathrm{NMR}$ analysis. Elemental Analysis calc'd (\%) for $\mathrm{C}_{47} \mathrm{H}_{42} \mathrm{ClIrN}_{2} \mathrm{O}_{2}$ : C 63.1, H 4.7, N 3.1; found: C 63.0, H 4.6, N 2.7.

1,3-bis(2-diphenylmethyl-4,6-dimethylphenyl)-4,5-dihydroimidazole2-selenone (15). 4 (129.8 mg, $0.201 \mathrm{mmol}$ ), KOtBu (78.5 mg, 0.700 $\mathrm{mmol}, 3.5$ equiv.), and selenium (102.4 mg, $1.297 \mathrm{mmol}, 6.5$ equiv.) were added to a vial fitted with a septum cap. The vial was evacuated, backfilled with argon, and charged with anhydrous THF $(2 \mathrm{~mL})$. The reaction was stirred for $24 \mathrm{~h}$ at room temperature. The solvent was removed in vacuo, and the residue was taken up in DCM and filtered through celite. The DCM solvent was removed in vacuo and the residue was washed with hexane to yield the product as a white powder. $63.5 \mathrm{mg}$, 
$0.092 \mathrm{mmol}, 46 \%$. The product is obtained as a ca. $3: 2$ mixture of rotamers (see text); some key signals for each rotamer can be identified. ${ }^{1} \mathrm{H}$ NMR $\left(\mathrm{CDCl}_{3}, 400 \mathrm{MHz}\right): \delta_{\mathrm{H}} 7.40-7.12(\mathrm{~m}, \mathrm{ArCH}), 7.02(\mathrm{~s}, \mathrm{Ar} \mathrm{CH}$ ) 6.68 (s, $2 \mathrm{H}, \mathrm{Ar} \mathrm{CH}$, rot. B), 6.60 (s, $2 \mathrm{H}, \mathrm{Ar} \mathrm{CH}$, rot. A), 6.00 (s, $2 \mathrm{H}, \mathrm{CHPh}_{2}$ rot. B), 5.92 (s, $2 \mathrm{H}, \mathrm{CHPh}_{2}$, rot. $\left.\mathrm{A}\right), 3.50-3.38\left(\mathrm{~m}, 2 \mathrm{H}, \mathrm{N}\left(\mathrm{CH}_{2}\right)_{2} \mathrm{~N}\right.$, rot. $\left.\mathrm{B}\right)$, 3.24-3.10 (m, $2 \mathrm{H}, \mathrm{N}\left(\mathrm{CH}_{2}\right)_{2} \mathrm{~N}$, rot. A), 2.85-2.72 (m, $2 \mathrm{H}, \mathrm{N}\left(\mathrm{CH}_{2}\right)_{2} \mathrm{~N}$, rot. $\left.\mathrm{B}\right)$, 2.48-2.37 (m, $2 \mathrm{H}, \mathrm{N}\left(\mathrm{CH}_{2}\right)_{2} \mathrm{~N}$, rot. A), $2.38\left(\mathrm{~s}, \mathrm{CH}_{3}\right), 2.30\left(\mathrm{~s}, \mathrm{CH}_{3}\right), 2.24$ (s, $\left.\mathrm{CH}_{3}\right) .{ }^{13} \mathrm{C}\left\{{ }^{1} \mathrm{H}\right\}$ NMR $\left(\mathrm{CDCl}_{3}, 101 \mathrm{MHz}\right)$ : $\delta \mathrm{c} 181.5$ (C-Se, rot. B), 181.2 (CSe, rot. A), 144.2 ( $\operatorname{Ar} C), 143.8(\operatorname{Ar} C), 143.5(\operatorname{Ar~C}), 143.4(\operatorname{Ar~C}), 143.2$ ( $\mathrm{Ar} \mathrm{C}), 142.7$ ( $\mathrm{Ar} \mathrm{C}), 138.4(\mathrm{Ar} \mathrm{C}), 138.3$ (Ar C), 136.4 (Ar C), $135.3(\mathrm{Ar}$ C), $135.2(\mathrm{Ar} \mathrm{C}), 130.62(\mathrm{Ar} \mathrm{CH}), 130.55(\mathrm{Ar} \mathrm{CH}), 130.1(\mathrm{Ar} \mathrm{CH}), 129.9$ $(\mathrm{Ar} \mathrm{CH}), 129.8$ ( $\mathrm{Ar} \mathrm{CH}), 129.7(\mathrm{Ar} \mathrm{CH}), 129.64(\mathrm{Ar} \mathrm{CH}), 129.57(\mathrm{Ar} \mathrm{CH})$, 128.6 ( $\mathrm{Ar} \mathrm{CH}), 128.3(\mathrm{Ar} \mathrm{CH}), 126.7(\mathrm{Ar} \mathrm{CH}), 126.6(\mathrm{Ar} \mathrm{CH}), 126.4(\mathrm{Ar}$ $\mathrm{CH}), 51.9\left(\mathrm{CHPh}_{2}\right.$, rot. A), $51.7\left(\mathrm{CHPh}_{2}\right.$, rot. $\left.\mathrm{B}\right), 49.2\left(\mathrm{~N}\left(\mathrm{CH}_{2}\right)_{2} \mathrm{~N}\right.$, rot. $\left.\mathrm{B}\right)$, $48.6\left(\mathrm{~N}\left(\mathrm{CH}_{2}\right)_{2} \mathrm{~N}\right.$, rot. A), $21.6\left(\mathrm{CH}_{3}\right), 18.6\left(\mathrm{CH}_{3}\right), 18.5\left(\mathrm{CH}_{3}\right) .{ }^{77}$ Se NMR $\left(\mathrm{CDCl}_{3}, 76 \mathrm{MHz}\right.$ ): $\delta$ se 150.8 (rot. B), 139.5 (rot. A). HRMS. $\mathrm{m} / \mathrm{z}$ calc'd for $\mathrm{C} 45 \mathrm{H} 43 \mathrm{~N} 2 \mathrm{Se}[\mathrm{M}+\mathrm{H}]+691.2590$; found 691.2573 .

Hydrosilylation reaction. A microwave tube equipped with a stir bar was charged with benzophenone $(186.6 \mathrm{mg}, 1.02 \mathrm{mmol})$, potassium tertbutoxide $(23.2 \mathrm{mg}, 0.21 \mathrm{mmol})$, and $9(21.3 \mathrm{mg}, 0.03 \mathrm{mmol})$. The tube was sealed with a septum-fitted crimp cap, and evacuated and backfilled with argon, before anhydrous toluene $(2 \mathrm{~mL})$ was added. The reaction was heated at $80{ }^{\circ} \mathrm{C}$ for 10 minutes, before the addition of triethylsilane $(0.79 \mathrm{~mL}, 5 \mathrm{mmol}, 5$ equiv.). Samples (ca. $20 \mu \mathrm{L}$ ) were withdrawn every hour for six hours, diluted in chloroform, filtered, and submitted for analysis by GC-FID, which was calibrated using authentic samples of the starting material and product.

\section{Acknowledgements}

We thank the University of Strathclyde for funding (consumables and facilities funding for GL; Chancellors Fellowship to DJN). We are grateful to GSK Global Manufacturing and Supply (Montrose, UK) for a studentship via the GSK/Strathclyde Centre for Doctoral Training in Medicinal Chemistry and Chemical Synthesis (SHW). We thank Mr Gavin Bain, Mr Alexander Clunie Mr Craig Irving, Ms Patricia Keating, and Dr John Parkinson for assistance with technical and analytical facilities. We are grateful to the EPSRC National Mass Spectrometry Facility at the University of Swansea for high resolution mass spectrometry services; we particularly wish to thank them for their service to the synthetic chemistry community in the UK and express our disappointment at the recent decision to discontinue the funding of this valuable facility. Some of the results were obtained using the EPSRC funded Archie-WeSt High Performance Computer (www.archie-west.ac.uk; EPSRC grant no. EP/K000586/1). We thank Mr Stephen Boyer at the London Metropolitan University for conducting some of the elemental analyses reported in this manuscript.

Keywords: $N$-heterocyclic carbenes $\cdot$ coordination chemistry • organometallic chemistry

[1] S. Díez-González, N. Marion, S. P. Nolan, Chem. Rev. 2009, 109 3612-3676.

[2] M. N. Hopkinson, C. Richter, M. Schedler, F. Glorius, Nature 2014, 510, 485-496.

[3] E. Peris, Chem. Rev. 2018, 118, 9988-10031.
[4] H. V. Huynh, Chem Rev 2018, 118, $9457-9492$

[5] D. J. Nelson, S. P. Nolan, Chem. Soc. Rev. 2013, 42, 6723-6753.

[6] H. Clavier, S. P. Nolan, Chem. Commun. 2010, 46, 841-861.

[7] A. Gomez-Suarez, D. J. Nelson, S. P. Nolan, Chem Commun (Camb) 2017, 53, 2650-2660.

[8] C. A. Tolman, Chem. Rev. 1977, 77, 313-348

[9] L. Benhamou, E. Chardon, G. Lavigne, S. Bellemin-Laponnaz, V. César, Chem. Rev. 2011, 111, 2705-2733.

[10] P. Shaw, A. R. Kennedy, D. J. Nelson, Dalton Trans. 2016, 45, $11772-$ 11780.

[11] R. Dorta, E. D. Stevens, N. M. Scott, C. Costabile, L. Cavallo, C. D. Hoff, S. P. Nolan, J. Am. Chem. Soc. 2005, 127, 2485-2495.

[12] S. Fantasia, J. L. Petersen, H. Jacobsen, L. Cavallo, S. P. Nolan, Organometallics 2007, 26, 5880-5889.

[13] O. Back, M. Henry-Ellinger, C. D. Martin, D. Martin, G. Bertrand, Angew. Chem. Int. Ed. 2013, 52, 2939-2943.

[14] A. Liske, K. Verlinden, H. Buhl, K. Schaper, C. Ganter, Organometallics 2013, 32, 5269-5272.

[15] S. V. C. Vummaleti, D. J. Nelson, A. Poater, A. Gomez-Suarez, D. B. Cordes, A. M. Z. Slawin, S. P. Nolan, L. Cavallo, Chem. Sci. 2015, 6, 1895-1904.

[16] K. Verlinden, H. Buhl, W. Frank, C. Ganter, Eur. J. Inorg. Chem. 2015, 2015, 2416-2425.

[17] D. J. Nelson, Eur. J. Inorg. Chem. 2015, 2015, 2012-2027.

[18] A. J. Arduengo III, R. Krafczyk, R. Schmutzler, H. A. Craig, J. R. Goerlich, W. J. Marshall, M. Unverzagt, Tetrahedron 1999, 55, 1452314534.

[19] M. Tsimerman, D. Mallik, T. Matsuo, T. Otani, K. Tamao, M. G. Organ, Chem. Commun. 2012, 48, 10352-10354.

[20] R. Visbal, A. Laguna, M. C. Gimeno, Chem. Commun. 2013, 49, 56425644 .

[21] O. Santoro, A. Collado, A. M. Z. Slawin, S. P. Nolan, C. S. J. Cazin, Chem. Commun. 2013, 49, 10483-10485.

[22] H. Plenio, R. Savka, Dalton Trans. 2015, 44, 891-893.

[23] C. D. Abernethy, A. H. Cowley, R. A. Jones, J. Organomet. Chem. 2000, 596, 3-5.

[24] The crystallographic data for these complexes is contained within the CCDC CSD under entries XXXX - XXXX. These data can be obtained free of charge from https://www.ccdc.cam.ac.uk/structures/.

[25] A total of 58 electron equivalents were removed from approximately 871 cubic Angstroms of unit cell volume.

[26] A. Spek, Acta Crystallographica Section C 2015, 71, 9-18.

[27] L. Falivene, R. Credendino, A. Poater, A. Petta, L. Serra, R. Oliva, V. Scarano, L. Cavallo, Organometallics 2016, 35, 2286-2293.

[28] A. Poater, B. Cosenza, A. Correa, S. Giudice, F. Ragone, V. Scarano, L. Cavallo, Eur. J. Inorg. Chem. 2009, 2009, 1759-1766.

[29] D. J. Nelson, F. Nahra, S. R. Patrick, D. B. Cordes, A. M. Z. Slawin, S. P. Nolan, Organometallics 2014, 33, 3640-3645

[30] F. Nahra, K. Van Hecke, A. R. Kennedy, D. J. Nelson, Dalton Trans 2018

[31] H. Buhl, K. Verlinden, C. Ganter, S. B. Novaković, G. A. Bogdanović Eur. J. Inorg. Chem. 2016, 2016, 3389-3395.

[32] S. Diez-Gonzalez, E. C. Escudero-Adan, J. Benet-Buchholz, E. D. Stevens, A. M. Z. Slawin, S. P. Nolan, Dalton Trans. 2010, 39, 75957606.

[33] M. J. Frisch, G. W. Trucks, H. B. Schlegel, G. E. Scuseria, M. A. Robb, J. R. Cheeseman, G. Scalmani, V. Barone, B. Mennucci, G. A Petersson, H. Nakatsuji, M. Caricato, X. Li, H. P. Hratchian, A. F Izmaylov, J. Bloino, J. Zheng, L. Sonnenberg, M. Hada, M. Ehara, K. Toyota, R. Fukuda, J. Hasegawa, M. Ishida, T. Nakajima, Y. Honda, O Kitao, T. Nakai, T. Vreven, J. A. Montgomery, J. E. Peralta, F. Ogliaro, M. Bearpark, J. J. Heyd, E. Brothers, K. N. Kudin, V. N. Staroverov, R. Kobayashi, J. Normand, K. Raghavachari, A. Rendell, J. C. Burant, S S. Iyengar, J. Tomasi, M. Cossi, N. Rega, J. M. Millam, M. Klene, J. E. Knox, J. B. Cross, V. Bakken, C. Adamo, J. Jaramillo, R. Gomperts, R. 
E. Stratmann, O. Yazyev, A. J. Austin, C. Cammi, C. Pomelli, J. W. Ochterski, R. L. Martin, K. Morokuma, V. G. Zakrzewski, G. A. Voth, P. Salvador, J. J. Dannenberg, S. Dapprich, A. D. Daniels, O. Farkas, J. B. Foresman, J. V. Ortiz, J. Cioslowski, D. J. Fox, Gaussian, Inc., Wallingford CT, 2009.
[34] G. R. Fulmer, A. J. M. Miller, N. H. Sherden, H. E. Gottlieb, A Nudelman, B. M. Stoltz, J. E. Bercaw, K. I. Goldberg, Organometallics 2010, 29, 2176-2179. 
Entry for the Table of Contents (Please choose one layout)

Layout 1:

\section{FULL PAPER}

Text for Table of Contents

*one or two words that highlight the emphasis of the paper or the field of the study

Layout 2:

\section{FULL PAPER}

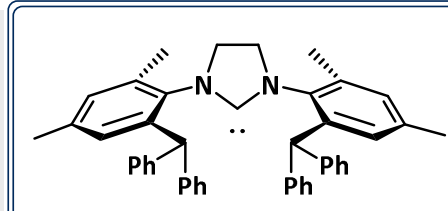

A bulky carbene with a saturated backbone has been prepared, and coordinated to several transition metals. The TEP, $\% V_{b u r}$, and $\delta_{\text {se }}$ have also been measured.
SIPaul: A new sterically bulky 4,5-dihydroimidazol-2-ylidene $\mathrm{N}$-heterocyclic carbene ligand

$\% V_{\text {bur }}$ up to $47 \%$

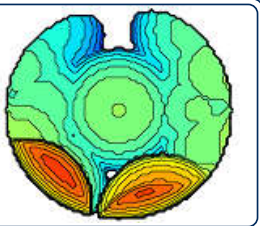

\section{Key Topic*}

Author(s), Corresponding Author(s)*

Page No. - Page No.

Title

. width: $5.5 \mathrm{~cm}$; max. height: $5.0 \mathrm{~cm}$; NOTE: the final letter height should not be less than $2 \mathrm{~mm}$.)) 